\title{
Corporate Takeovers in Malaysia: The Determinants of Financing Decision
}

\author{
CAO DINH KIEN \\ Foreign Trade University (Hanoi campus) - caokien@ftu.edu.vn \\ NGUYEN THU THUY \\ Foreign Trade University (Hanoi campus) - thuy.nt@ftu.edu.vn \\ NGO THI THU HA
}

Foreign Trade University (Hanoi campus) - ngothithuha021993@gmail.com

This research was supported and funded by Vietnam's National Foundation for Science and Technology Development (NAFOSTED) under grant number II3.1-2013.28.

\section{ARTICLE INFO ABSTRACT}

Article history:

Received:

Aug. 62015

Received in revised form:

Oct. 92015

Accepted:

Mar. 252016
In this article we examine the role of potential factors influencing the choice of payment method in takeover transactions of Malaysian acquirers. We document that the financial leverage, the size of acquiring firms, the relative size of the transactions to acquiring firms, and the high technology status of the targets are key determinants to explain the methods of payment in their transactions. Moreover, the acquirers are found to be able to use equity to finance their foreign M\&A transactions during the credit constraint periods.

Keywords:

Mergers, acquisitions, method of payment, financing decision, Malaysia. 


\section{Introduction}

Mergers and acquisitions (M\&As) have become a remarkable business phenomenon around the globe. As one of the viable turnaround options for restoring health of distressed companies which should be seen as a means for their survival and growth in the $21^{\text {st }}$ century, they are popularly employed by investors especially in the advanced economies of the world to engender large and financially viable companies, which in turn facilitate the rapid growth and development of the economies. On the other hand, they are also adopted by investors in developing countries, where today's unfolding scenario requires the pooling together of resources for more optimal use in order to ensure economic rationalization, economies of scale, and survival and profitable growth. Thus, M\&As are an important means by which companies achieve sound economies of scale, remove inefficient management, or respond to economic shocks (Rachel et al., 2004). Moreover, with the pace of globalization, many companies go beyond the national borders of the countries to expand, diversify, or consolidate their businesses, and international M\&As, as a result, are among the most frequently used corporate strategies (Larsen, 2007). These popular forms of business investments gained popularity in the business world with Malaysia being no exception since the 1990s (Song et al., 2008).

Selection of payment methods is clearly one of the most important aspects of structuring the deal for the fact that it has a significant influence on the financial status, capital structure, and controlling structure of the surviving purchasing companies after transactions (Faccio \& Masulis, 2005). In 1988 nearly 60\% of the value of large deals, those with value of over $\$ 100$ million, was paid by cash, and less than $2 \%$ of the value, by stock. However, within merely 10 years the profile was almost reversed, with about $50 \%$ and only $17 \%$ of the value of large deals paid by stock and by cash in 1998 respectively. This shift has profound ramifications for the shareholders of both acquiring and acquired companies (Rappaport \& Sirower, 1999).

While a large number of studies related to methods of payment in M\&As have been conducted in developed countries, such as the US, the UK, Canada, and so on, there is a limited number of research done in the context of developing countries. In this paper we examine the determinants of the medium of exchange in M\&A transactions involving Malaysian acquiring companies. 
It should be well noticed that Malaysia is a key participant in the negotiation of the Trans-Pacific Partnership free trade agreement and, together with the nine other ASEAN members, would form the ASEAN Economic Community in 2015. The country has transformed itself from a producer of raw materials, such as tin and rubber, in the 1970s into an emerging multi-sector economy, becoming a leading exporter of electrical appliances, electronic parts and components, palm oil, and natural gas. As a relatively open economy, Malaysia is a vital part of the East Asia manufacturing network; the business environment encourages the development of a vibrant private sector. Additionally, it scores well in the area of open markets measured by trade freedom, investment freedom, and financial freedom, compared to the global averages. The financial sector is robust, while foreign investment is being permitted to a greater degree.

To the best of our knowledge, this is the first empirical study investigating the difference in the key factors determining the methods of payment of Malaysian acquirers in both cross-border and domestic deals. We find that the financial leverage, the size of acquiring firms, the relative size of the transactions to acquiring firms, and the high technology status of the targets are major determinants to explain the methods of payment in transactions of Malaysian acquirers. Moreover, Malaysian acquirers are able to use equity to finance their foreign $M \& A$ transactions during the credit constraint periods.

\section{Literature review}

M\&As are one of the most significant and largest investment decisions that companies and corporate strategists face. They are also one of the most complex transactions usually involving simultaneous decisions on how to engage in a merger or acquisition, how to finance and pay for an M\&A, and how to align the financing requirements with the target capital structure (Bessler et al., 2011).

The method of payment plays an important role in the success of an M\&A transaction because cash and stock offers differ regarding these transaction risks. These differences are due to information asymmetries and variation in their pricing mechanisms. In addition, stock and cash offers are also different from a governance perspective because stock offers may substantially change the ownership structure of the acquirer. In fact, most practitioners view the method of payment, financing alternatives, and capital structure choices as a joint decision in setting the terms of a deal (Bruner, 2004). 
One of the most extensively researched areas in finance has been whether mergers create value for the shareholders of the target and acquirer firms. There are various studies examining the relation between the method of payment in M\&As and operating performance of targets and acquirers after M\&A deals. For example, Travlos (1987), Wansley et al. (1987), Amihud et al. (1990), Servaes (1991), and Brown and Ryngaert (1991) documented significantly negative average announcement returns to acquirers when the method of payment is by stock rather than by cash. One dominant explanation for this pattern is that an offer to pay shares for an M\&A deal will be seen by market participants as a signal that the stocks are overvalued (Myers \& Majluf, 1984). Although extant literature documented significant relations between the form of financing choice and announcement returns, some research found no evidence that the method of payment provides information regarding the firm's future operating performance such as Healy et al. (1992) and Heron and Lie (2002). The apparent inconsistency between the results could be attributable to differences in the underlying samples.

Harris and Raviv (1988) and Stulz (1988) hypothesized that managers who value control and hold a significant ownership fraction of their firm's stock will be unwilling to dilute their holdings and risk a loss of control by issuing stock to finance investment. Amihud et al. (1990) developed this hypothesis by testing the relation between corporate control considerations and the means of investment financing-cash (and debt) or stock. In support of this hypothesis they found evidence that the larger the managerial ownership fraction of the acquiring firm, the more likely the use of cash financing. Moreover, Ghosh and Ruland (1998) illustrated that target firm managerial ownership is even more important than that of acquirers in explaining the methods of payment in M\&A deals. If managers with high ownership in targets negotiate for stock to exercise influence in combined firms, their pro forma ownership in the combined firms after acquisitions is a determinant of the method of acquisition.

Martin (1996), Boateng and Bi (2014), and Boone et al. (2014) examined the motives underlying the payment method in corporate acquisitions. They considered the size of target and acquiring firms, their investment opportunities, and acquirer's cash availability as determinants of the method of payment. The findings showed that there is a positive association between the acquirer's growth opportunities and the likelihood of stock financing. In addition, the higher the pre-acquisition market value of acquiring firm, the more likely it is for the firm to use stock as the method of payment in an M\&A deal. In contrast, if the acquirer has more cash availability, it tends to use cash instead. 
Sudarsanam and Mahate (2003), additionally, reported a significant correlation between financial status and the choice of payment method. Their findings indicated that acquiring firms with high growth or high investment opportunities (glamour acquirers) are more likely to use equity as a method of payment. Furthermore, they demonstrated that glamour acquiring firms offering equity suffer more serious underperformance than those offering cash on the long- run post-acquisition.

Faccio and Masulis (2005) conducted an investigation into determinants of M\&A financing decisions using a large sample of European acquirers for publicly and privately held targets over the period from 1997 to 2000. Overall, they detected much more concentrated ownership in Europe and stronger effects on the M\&A financing choice from acquirer corporate governance concerns and financial conditions than Martin (1996) did for the case of the US. They also noted that if an acquirer is on a bank's board of directors, it is easier for the firm to access debt market, resulting in a larger portion of cash financing used in M\&A deals.

When using cash as a method of payment, the purchasing company offers a fixed amount it is willing to pay in exchange for the target shares (Bessler et al., 2011). In a cash deal the relationship between the stockholders of purchasing firm and target firm is clear. When the deal is closed, the target shareholders divest from the firm in exchange for cash. The purchasing company has total rights of the target company from its former shareholders. Stockholders of the purchasing company will not lose their control to the new surviving company; therefore, ownership will not be diluted by any means. However, the shareholders of the target firm are not prevented from investing money in the acquirer's stock, thus continuing to be shareholders.

In a stock deal there is uncertainty about the actual price that the target shareholders receive. Typically, they are offered a specific number of shares of the acquirer or of the newly combined company in exchange for their share. Consequently, the precise price that is paid in these deals is conditional on the stock price movements of the acquirer's shares until closing (Bessler et al., 2011). Furthermore, when the deal is closed, in a stock deal, former shareholders of target firm, as well as former shareholders of the purchasing firm, all become shareholders of the new surviving firm after M\&As. In some cases, the shareholders of the acquired company can end up owning most of the company that bought their shares. Also, in a stock deal the value and risk are shared between both 
parties in proportion to the percentage of the combined company that the acquiring and selling shareholders each will own.

\section{Hypotheses development}

Following Cao and Madura (2011), we classify potential determinants of method of payment into three categories: determinants reflecting cash constraints imposed on acquirers, determinants reflecting asymmetric information between acquirers and target firm, and determinants reflecting country risk and governance.

\subsection{Determinants reflecting cash constraints}

We hypothesize that firms using cash payment method commonly require issuing new debts; thus, the financial status of acquiring firms before M\&As also has a great influence on the choice of medium of exchange. Faccio and Masulis (2005) and Boateng and $\mathrm{Bi}$ (2014) argued that firms with high leverage are constrained in their ability to fund investment by debt since issuing new debts raises the probability of financial distress and bankruptcy costs. As a result, we hypothesize that acquirers with a high degree of financial leverage are more likely to use stock financing as their method of payment in M\&As. We choose DEBT, which is measured as total liabilities of acquirer divided by total asset of acquirer, to proxy for an acquirer's financial leverage.

H1: The acquirer's leverage has a positive relationship with the proportion of stock payment used in M\&A deals.

Faccio and Masulis (2005) provided an explanation as to how acquirers' size influences the financing choice. Due to the diversification characteristics of large firms, it is less likely for those firms to deal with the bankruptcy situation. Moreover, larger firms usually have a better reputation, making them easier to have access to debt markets. In addition, supposing that large firms have sufficiency of unused debt capacity or liquid assets, they tend to choose cash as a payment method since cash payment is the most simple method with a high-speed settlement and thorough ownership transferring. Furthermore, the use of cash allows larger acquirers to avoid the agency cost of equity. Thus, we assume that larger acquiring firms are more likely to use cash as the medium of exchange in M\&As. We measure acquirers' size by the variable SIZE, which is calculated as the log of pre-merger book value of acquirers' assets. 
H2: The acquirer's size has a negative relationship with the proportion of stock payment used in $M \& A$ deals.

As argued in Cao and Madura (2011), high technology firms usually require a large amount of money as initial investment for research and development. For that reason, the high-tech status of acquirers can be considered as a factor that represents cash constraint. In agreement with Jung et al. (1996), Martynova and Renneboog (2009) argued that firms with good investment opportunities have strong motivations to finance investment by issuing equity than debt. As a result, it is supposed that high-tech acquirers prefer to finance M\&A deals with equity. We use the dummy variable TECHBID as a proxy for high-tech status of acquirers. The dummy variable equals 1 if the acquirer has high-tech Standard Industrial Classification (SIC) codes and 0 otherwise.

H3: High-tech acquiring firms are more likely to use stock payment as a means of payment in $M \& A s$.

In line with Cao and Madura (2011), during the weak economic conditions, stock prices are more likely to decrease, preventing acquirers from issuing new stock to fund investment. However, under the crisis circumstances, there is limited access to debt markets. We choose the variable CRISIS to test the impact of crisis periods on the decision to finance M\&A transactions. Based on Johnson et al. (2000), Ivashina and Scharfstein (2010), and Arslan et al. (2006), we consider the periods of 1997-1998, 2001-2002, and 2007 crises in this study. CRISIS equals one if the transactions occur during these stages (from Q3/1997 to Q4/1998, from Q1/2001 to Q4/2002, and from Q3/2007 to Q4/2010), and equals 0 otherwise.

H4: The weak economic condition has a significant impact on the choice of medium of exchange in $M \& A s$.

Faccio and Masulis (2005) argued that firms selling subsidiaries often suffer financial distress. On the other hand, they might want to restructure and focus on their core business. Therefore, they have a strong preference for cash. In addition, unlisted sellers should have a strong demand for cash because of the highly concentrated characteristics of unlisted firm's ownership and the often imminent retirement of a controlling shareholder manager. Therefore, we expect that the proportion of cash payment in a deal is higher when the target firm is a subsidiary or an unlisted firm. We choose the dummy variable SUB as a proxy for public status of target firms. It equals 0 when target firms are public firms, and equals 1 otherwise. 
H5: There is a positive relationship between the publicly traded status of target firms and the proportion of stock payment in M\&As.

\subsection{Determinants reflecting asymmetric information}

The model of the issue-invest decision by Myers and Majluf (1984) assumes that the target firm's managers are aware of its firm's true value better than the acquiring firm's and that the management acts in the existing shareholders' interests. Therefore, if they believe that their firm is undervalued, they will prefer cash offer, and in contrast, if they believe their stock is overvalued, they will prefer stock offer. It shows that market participants see stock offer as a bad signal, and stock price will reduce afterward. In addition, Chemmanur et al. (2009) presented evidence that the greater the extent of information asymmetry faced by an acquirer in evaluating its target, the greater its likelihood of using a cash offer.

Hasen (1987) contributed to the asymmetric information modeling by considering the case where a target firm knows its value better than a potential acquirer, and the transacting process of a merger or acquisition is treated as a two-agent bargaining game under imperfect information. If the acquiring firm makes cash offer, the target firm accepts the offer only if its value is less than the offer made. To protect itself against this adverse selection, the acquirer should offer stock payment rather than cash payment because of the desirable contingent-pricing effect of stock. The target, using its information, will not always accept stock offer. Hansen's (1987) model pointed out the negative relationship between the probability of a stock offer and the target's size relative to the acquirer's size. Moreover, a relatively large target makes the bidder more vulnerable to major losses due to a bad investment decision (see Boone et al., 2014). Hence, acquirers have a tendency to use stock as a payment method in large deals. We suppose that cash payment is less likely to be used for relatively large deals. We use the variable RELSIZE, which equals the deal value divided by the premerger book value of acquirer's assets in dollars, to examine the impact of the relative size on the method of payment.

H6: The relative size of the deals has a positive relationship with the proportion of stock payment used in $M \& A$ deals.

According to Cao and Madura (2011), the less transparent issue in assets of high technology firms is less transparent and thus raises the problem of information asymmetry. Acquirers prefer to use a greater proportion of stock payment in transactions 
involving high-tech targets to share the risks of misvaluation between the two parties. Therefore, we hypothesize that there is a smaller proportion of cash used in M\&As if targets are high-tech companies. We use the dummy variable TECHSELL as a proxy for high technology status of the targets. The dummy variable equals 1 if the targets have high-tech Standard Industrial Classification (SIC) codes, and 0 otherwise.

H7: Acquiring firms are more likely to use stock payment method when purchasing high-tech targets.

The higher level of relatedness between the acquirer and the target, the less exposure of information asymmetry between the two parties, and thus the more acquirer's willingness of using a cash offer. Chemmanur et al. (2009) and Faccio and Masulis (2005) found evidence to support that point. We expect that if the two parties are in the same industry and thus have the same two-digit SIC code, there is a greater proportion of cash payment in the deal. We use the dummy variable RELATED to capture this effect. It equals 1 if acquirers and targets have the same two-digit SIC code, and 0 otherwise $^{1}$.

H8: The industry relatedness between acquirers and targets has a negative effect on the proportion of stock payment used in $M \& A s$.

\subsection{Determinants reflecting country risk and governance}

The target shareholders may be reluctant to accept an equity offer from foreign acquirers for several reasons. First, the acquiring firm may be less known in the target country. Secondly, according to Faccio and Masulis (2005), the target country's government may impose some restrictions on foreign equity investments. Consequently, we hypothesize that there is a positive relationship between cross-border deal and the proportion of cash payment in M\&A deals. We employ CROSS, a dummy that equals 1 if the acquiring firm and the target firm are in the same country, and 0 otherwise.

H9: The country relatedness between target and acquiring firms has a negative impact on the proportion of stock payment used in M\&As.

If target and acquiring companies are not in the same country, there arises an asymmetric information problem in terms of culture, legal system, regulation, economic policies, and so on, which poses a threat to acquiring firms. Henisz (2000) suggested that when doing business in a foreign country, the multinational firm should partner with the host-country firm; by that way, the multinational firm can protect itself from 
opportunistic expropriation by shifting some risks to sellers. Moreover, Rossi and Volpin (2004) documented that acquirers are more willing to use equity in a cross-border deal that is in the country with high shareholder protection, and in contrast, there are more cash deals in countries with lower shareholder protection.

H10: Acquirers use more equity payment when purchasing targets in a country that has a common law system and high economic freedom.

Following Cao and Madura (2011), we use two variables as proxies for country risk and corporate governance, which include:

(i) Economic freedom: This is the fundamental right of every human to control his or her own labor and property. In an economically free society not only should individuals be free to work, produce, consume, and invest in any way they please, but the government also allows labor, capital, and goods to move freely, and refrain from coercion or constraint of liberty beyond the extent necessity to protect and maintain the liberty itself. We collect the rating of economic freedom for each target country in the sample and employ the variable FREEDOM in our analysis. FREEDOM equals the log of the economic freedom rating of the target country; and

(ii) Legal system: Since common law systems have relatively strong shareholder rights, we use COMMON as a proxy for the influence of legal system on the choice of exchange medium. We set it equal to 1 if the target country has a common law system, and 0 otherwise.

\section{Data and methodology}

\subsection{Data}

We obtain our sample from the Thomson Financial SDC Platinum database. Only transactions that satisfy certain criteria are included in the sample. First, the data cover Malaysian acquirers only. Second, the transactions should have the announcement data from January 1, 1995 to December 31, 2012. Third, the deal value should not be less than USD10 million. Fourth, deals have to be completed, and deals' forms are mergers, acquisitions, or acquisitions of majority interest. The final sample has 313 observations. Moreover, we collect information about the economic freedom rating from the Heritage website and the legal system classification from the 'CIA World Factbook' website. Table 1 provides summary of the variables. 


\section{Table 1}

Definitions of variables ${ }^{2}$

\begin{tabular}{|c|c|c|}
\hline Variable & Definition & $\begin{array}{c}\text { Expected } \\
\text { sign }\end{array}$ \\
\hline DEBT & $\begin{array}{l}\text { Equals the total liabilities of acquirer divided by total asset of } \\
\text { acquirer }\end{array}$ & + \\
\hline SIZE & Equals the log of premerger book value of acquirer's assets & - \\
\hline TECHBID & $\begin{array}{l}\text { Equals } 1 \text { if the acquirers are high tech companies and } 0 \\
\text { otherwise }\end{array}$ & + \\
\hline CRISIS & $\begin{array}{l}\text { Equals } 1 \text { if the transactions happen during 1997-1998, 2001- } \\
2002 \text { and } 2007 \text { crisis (from Q3/1997 to Q4/1998, Q1/2001 to } \\
\text { Q4/2002, and from Q3/2007 to Q4/2010) and } 0 \text { otherwise }\end{array}$ & $-/+$ \\
\hline SUB & Equals 0 when target is a public firm and 1 otherwise & - \\
\hline RELSIZE & $\begin{array}{l}\text { Equals the deal value divided by premerger book value of } \\
\text { acquirer's assets }\end{array}$ & + \\
\hline TECHSELL & Equals 1 if the targets are high tech companies and 0 otherwise & + \\
\hline RELATED & $\begin{array}{l}\text { Equals } 1 \text { if acquirer and target are in the same industry and } 0 \\
\text { otherwise }\end{array}$ & - \\
\hline CROSS & $\begin{array}{l}\text { Equals } 0 \text { if acquiring firm and target firm are in the same } \\
\text { country and } 0 \text { otherwise }\end{array}$ & - \\
\hline FREEDOM & $\begin{array}{l}\text { Equals the log of the economic freedom rating of the target } \\
\text { country }\end{array}$ & + \\
\hline COMMON & $\begin{array}{l}\text { Equals } 1 \text { if target country is common law system and } 0 \\
\text { otherwise }\end{array}$ & + \\
\hline
\end{tabular}

\subsection{Methodology}

In accordance with Facio and Masulis (2005), we use a two boundary Tobit model, also called a censored regression model, to estimate the relationship between various explanatory variables and the stock proportion used in the transactions. The general model is as follows:

$$
y i^{*}=\beta X i^{\prime}+u i
$$


where ui is an independently distributed error term assumed to be normal with zero mean and variance $\sigma 2$.

If $0<\mathrm{yi}^{*}<100$ then $\mathrm{yi}=\mathrm{yi}^{*}$

If $\mathrm{yi}^{*} \leq 100$ then $\mathrm{yi}=100$

If $\mathrm{yi}^{*} \leq 0$ then $\mathrm{yi}=0$

When applying this model to our sample, the quasi-maximum likelihood (QML) White/Huber standard errors are used to correct for heteroskedasticity.

\section{Empirical results}

\subsection{Data description}

Table 2 presents the distribution of M\&A transactions by seller countries. Our sample comprises 313 acquisitions with total deal value of around USD51 billion. Domestic deals represent the largest group in our sample while cross-border deals just account for $16.18 \%$ of transaction numbers and $13.74 \%$ of deal values in the entire sample. A majority of cross-border deals involve Singapore targets (11.78\% of all targets), and other cross-border deals only account for $1.96 \%$ of transaction numbers. Some crossborder deals involve targets from developed countries, such as Australia, Canada, Germany, Hong Kong, Italy, the Netherlands, and the United Kingdom, while other deals involve targets from developing countries.

\section{Table 2}

M\&A transactions by target countries

\begin{tabular}{lcccc}
\hline Country of target & $\begin{array}{c}\text { Total value } \\
\text { of investment } \\
\text { (USD million ) }\end{array}$ & $\begin{array}{c}\text { Number } \\
\text { of transactions }\end{array}$ & $\begin{array}{c}\text { Percentage of } \\
\text { total value } \\
\text { of investment (\%) }\end{array}$ & $\begin{array}{c}\text { Percentage } \\
\text { of transactions (\%) }\end{array}$ \\
\hline Australia & 17.53 & 1 & $0.03 \%$ & $0.32 \%$ \\
British Virgin & 143.41 & 2 & $0.28 \%$ & $0.64 \%$ \\
Canada & 59.40 & 1 & $0.12 \%$ & $0.32 \%$ \\
Cayman Islands & 32.00 & 1 & $0.06 \%$ & $0.32 \%$ \\
China & 293.17 & 3 & $0.57 \%$ & $0.96 \%$ \\
Germany & 42.01 & 1 & $0.08 \%$ & $0.32 \%$
\end{tabular}




\begin{tabular}{lcccc}
\hline Country of target & $\begin{array}{c}\text { Total value } \\
\text { of investment } \\
\text { (USD million })\end{array}$ & $\begin{array}{c}\text { Number } \\
\text { of transactions }\end{array}$ & $\begin{array}{c}\text { Percentage of } \\
\text { total value } \\
\text { of investment (\%) }\end{array}$ & $\begin{array}{c}\text { Percentage } \\
\text { of transactions (\%) }\end{array}$ \\
\hline Hong Kong & 234.17 & 2 & $0.46 \%$ & $0.64 \%$ \\
India & 21.76 & 1 & $0.04 \%$ & $0.32 \%$ \\
Indonesia & 163.86 & 4 & $0.32 \%$ & $1.28 \%$ \\
Italy & 86.54 & 1 & $0.17 \%$ & $0.32 \%$ \\
Malaysia & $42,788.45$ & 270 & $83.82 \%$ & $86.26 \%$ \\
Mauritius & 263.33 & 2 & $0.52 \%$ & $0.64 \%$ \\
The Netherlands & 839.00 & 1 & $1.64 \%$ & $0.32 \%$ \\
The Philippines & 30.77 & 1 & $0.06 \%$ & $0.32 \%$ \\
Singapore & $6,015.75$ & 21 & $11.78 \%$ & $6.71 \%$ \\
The United Kingdom & 15.69 & 1 & $0.03 \%$ & $0.32 \%$ \\
Total & $51,046.84$ & 313 & $100.00 \%$ & $100.00 \%$ \\
\hline
\end{tabular}

Table 3 shows the volume of M\&A transactions over time. M\&A activity increases in terms of the total number of transactions and the total deal value since 1999. The increase might be explained by the fact that Malaysia suffered the Asian financial crisis of 1997-1998, but after that the economy rebounded quickly, continuing to post solid growth rates, averaging 5.5\% per year from 2000 to 2008. As noticed, in periods of financial crisis (from Q1/2001 to Q4/2002 and from Q3/2007 to Q4/2010), M\&A activity continues to decrease regarding the total number of deals and the total deal value. M\&A activity reaches its highest point in the total number of deals in 2003, after the period of financial crisis 2001-2002. Moreover, there is a high volatility in the total deal value. The total deal value gets the peak at USD14,375.02 million in 2006 before the beginning of the financial crisis. However, it plummets in the next year, almost 9.5 times. 


\section{Table 3}

M\&A transactions by years

\begin{tabular}{|c|c|c|c|c|}
\hline Year & $\begin{array}{l}\text { Total value } \\
\text { of investment } \\
\text { (million } \$ \text { ) }\end{array}$ & $\begin{array}{c}\text { Number } \\
\text { of transactions }\end{array}$ & $\begin{array}{c}\text { Percentage of } \\
\text { total value } \\
\text { of investment }(\%)\end{array}$ & $\begin{array}{c}\text { Percentage } \\
\text { of total transaction }(\%)\end{array}$ \\
\hline 2012 & $1,942.41$ & 15 & $3.81 \%$ & $4.79 \%$ \\
\hline 2011 & $1,767.30$ & 23 & $3.46 \%$ & $7.35 \%$ \\
\hline 2010 & $2,162.42$ & 12 & $4.24 \%$ & $3.83 \%$ \\
\hline 2009 & $2,439.87$ & 10 & $4.78 \%$ & $3.19 \%$ \\
\hline 2008 & $4,607.11$ & 20 & $9.03 \%$ & $6.39 \%$ \\
\hline 2007 & $1,521.94$ & 28 & $2.98 \%$ & $8.95 \%$ \\
\hline 2006 & $14,375.02$ & 22 & $28.16 \%$ & $7.03 \%$ \\
\hline 2005 & $3,907.06$ & 12 & $7.65 \%$ & $3.83 \%$ \\
\hline 2004 & 929.73 & 20 & $1.82 \%$ & $6.39 \%$ \\
\hline 2003 & $3,956.97$ & 40 & $7.75 \%$ & $12.78 \%$ \\
\hline 2002 & $1,352.04$ & 24 & $2.65 \%$ & $7.67 \%$ \\
\hline 2001 & $2,408.94$ & 26 & $4.72 \%$ & $8.31 \%$ \\
\hline 2000 & $1,644.03$ & 14 & $3.22 \%$ & $4.47 \%$ \\
\hline 1999 & $3,060.79$ & 17 & $6.00 \%$ & $5.43 \%$ \\
\hline 1998 & 702.18 & 6 & $1.38 \%$ & $1.92 \%$ \\
\hline 1997 & $1,321.97$ & 8 & $2.59 \%$ & $2.56 \%$ \\
\hline 1996 & $1,777.63$ & 6 & $3.48 \%$ & $1.92 \%$ \\
\hline 1995 & $1,169.44$ & 10 & $2.29 \%$ & $3.19 \%$ \\
\hline Total & $51,046.84$ & 313 & $100 \%$ & $100 \%$ \\
\hline
\end{tabular}

Table 4 shows that the sample includes 144 (46.01\%) pure cash deals, $46(14.70 \%)$ pure stock deals, and 123 (39.30\%) mixed payment deals. The total value of mixed payment deals accounts for more than $50 \%$ of total investment value. 


\section{Table 4}

M\&A transactions by financing choice

\begin{tabular}{lcccc}
\hline Type of payment & $\begin{array}{c}\text { Total value of } \\
\text { investment (USD } \\
\text { million) }\end{array}$ & $\begin{array}{c}\text { Number of } \\
\text { transactions }\end{array}$ & $\begin{array}{c}\text { Percentage of } \\
\text { total value of } \\
\text { investment (\%) }\end{array}$ & $\begin{array}{c}\text { Percentage of } \\
\text { transactions (\%) }\end{array}$ \\
\hline Cash only & $19,074.91$ & 144 & $37.37 \%$ & $46.01 \%$ \\
Stock only & $5,421.40$ & 46 & $10.62 \%$ & $14.70 \%$ \\
Mixed payment & $26,550.53$ & 123 & $52.01 \%$ & $39.30 \%$ \\
Total & $51,046.84$ & 313 & $100.00 \%$ & $100.00 \%$ \\
\hline
\end{tabular}

\subsection{Univariate results}

Table 5 presents the descriptive statistics of the independent variables. It shows that the characteristics that reflect cash constraints, asymmetric information, and countryspecific aspects are quite different across categories of payment methods. Acquirers financing deals with cash have the highest average SIZE, while acquirers financing deals with stock have the lowest average SIZE. This evidence once again strengthens our hypothesis that larger acquirer firms are more likely to use cash as exchange medium in M\&A deals.

\section{Table 5}

Descriptive statistics of variables by financing choice

\begin{tabular}{lcccccc}
\hline \multicolumn{1}{c}{ Payment method } & \multicolumn{2}{c}{ Cash only } & \multicolumn{2}{c}{ Mixed payment } & \multicolumn{2}{c}{ Stock only } \\
\hline \multirow{2}{*}{ DEBT } & Mean & Median & Mean & Median & Mean & Median \\
SIZE & 0.48 & 0.45 & 0.56 & 0.46 & 0.52 & 0.48 \\
TECHBID & 2.80 & 2.74 & 2.48 & 2.44 & 2.23 & 2.33 \\
CRISIS & 0.03 & 0.00 & 0.03 & 0.00 & 0.04 & 0.00 \\
SUB & 0.32 & 0.00 & 0.37 & 0.00 & 0.28 & 0.00 \\
RELSIZE & 0.51 & 1.00 & 0.58 & 1.00 & 0.48 & 0.00 \\
TECHSELL & 0.18 & 0.08 & 0.94 & 0.18 & 1.69 & 0.34 \\
RELATED & 0.03 & 0.00 & 0.04 & 0.00 & 0.07 & 0.00 \\
& 0.31 & 0.00 & 0.26 & 0.00 & 0.28 & 0.00
\end{tabular}




\begin{tabular}{lcccccc}
\hline \multicolumn{1}{c}{ Payment method } & \multicolumn{2}{c}{ Cash only } & \multicolumn{2}{c}{ Mixed payment } & \multicolumn{2}{c}{ Stock only } \\
\hline & Mean & Median & Mean & Median & Mean & Median \\
\hline CROSS & 0.19 & 0.00 & 0.17 & 0.00 & 0.04 & 0.00 \\
FREEDOM & 1.86 & 1.85 & 1.85 & 1.85 & 1.85 & 1.85 \\
COMMON & 0.96 & 1.00 & 0.94 & 1.00 & 1.00 & 1.00 \\
\hline
\end{tabular}

The variable RELSIZE in pure stock deals is significantly larger than that in pure cash deals (9.53 times larger), which is convincing evidence supporting our presumption that cash is less likely to be used for a relatively large-value deal. We are also aware that acquirer financing deals with stock have the highest average TECHSELL, supporting our prediction that there is a smaller proportion of cash used in a deal if the seller is a high tech company. In addition, consistent with our earlier hypothesis, the likelihood of the acquirer and target in the same country is highest in pure cash deals and lowest in pure stock deals. Furthermore, the average FREEDOM of the target country is highest for only cash deals, and the average COMMON is highest for only stock deals.

\subsection{Multivariate results}

5.3.1. Results for the full sample of Malaysian acquirers

Table 6 presents the results achieved by applying the Tobit regression to the full sample in order to test variables that may influence the method of payment in M\&A transactions of Malaysian acquirers ${ }^{3}$. There are two models reflecting the target country governance, and only one of them is included in any model. The results show that several variables measuring cash constraints and reflecting asymmetric information are significant, which supports our hypothesis regarding how cash constraints and asymmetric information affect the choice of the exchange medium in M\&A transactions.

\section{Table 6}

Regression results for full sample

\begin{tabular}{lcccc}
\hline \multirow{2}{*}{ Variable } & \multicolumn{2}{c}{ Model 1 } & \multicolumn{2}{c}{ Model 2 } \\
\cline { 2 - 5 } & Coefficient & p-value & Coefficient & p-value \\
\hline C & -49.0668 & 0.9174 & -5.9402 & 0.9149 \\
DEBT & 43.2334 & $0.0890^{*}$ & 43.7707 & $0.0837^{*}$ \\
SIZE & -31.6189 & $0.0006^{* * *}$ & -32.0171 & $0.0004^{* * *}$
\end{tabular}




\begin{tabular}{lcccc}
\hline \multirow{2}{*}{ Variable } & \multicolumn{2}{c}{ Model 1 } & \multicolumn{2}{c}{ Model 2 } \\
\cline { 2 - 5 } & Coefficient & p-value & Coefficient & p-value \\
\hline TECHBID & -33.2111 & 0.4297 & -38.1634 & 0.3413 \\
CRISIS & -8.2948 & 0.5511 & -6.6647 & 0.6250 \\
SUB & -7.8650 & 0.5570 & -6.7949 & 0.6064 \\
RELSIZE & 6.4814 & $0.0056^{* * *}$ & 6.7216 & $0.0043^{* * *}$ \\
TECHSELL & 60.9770 & $0.0500^{* *}$ & 59.7886 & $0.0463 * *$ \\
RELATED & -2.8144 & 0.8521 & -4.1908 & 0.7783 \\
CROSS & -47.8976 & $0.0502 * *$ & -33.3288 & 0.1658 \\
FREEDOM & 49.3177 & 0.8473 & & 0.3445 \\
COMMON & & & 48.4836 & \\
Adj R-squared & 0.0443 & & 0.0456 & 312 \\
\multicolumn{1}{c}{ Total obs. } & 310 & & 3 & \\
\hline
\end{tabular}

Note: $* * *, * *$, and $*$ denote significance levels at $0.01,0.05$ and 0.10 respectively.

The results indicate that the debt ratio of an acquirer has a significant and positive impact on the proportion of stock used as a means of payment in both models at $10 \%$ level. Financially constrained acquirers with high leverage are more likely to use stock as the method of payment in M\&A deals, which is consistent with acquirers' concerns about substantially raising their likelihood of bankruptcy. If the acquirer's debt ratio reveals a $1 \%$ increase, the expected equity payment would increase by $43 \%$ while holding all other variables in the model constant. The result is in line with the evidence of Faccio and Masulis (2005) found in M\&A transactions in the sample of European acquirers. Moreover, we find that the coefficient of SIZE is negatively significant at $1 \%$ level in both models, which is significant evidence supporting our argument that acquirers with larger size are more likely to use cash since they have better reputation, which makes it easier to have access to funding. If the log of premerger book value of acquirer's assets increases by one basis point, the expected equity payment would decrease by $32 \%$ while holding all other variables in the model constant. The result is also in line with the evidence shown by Cao and Madura (2011) in the asset sell-off transactions' sample of US sellers. 
We also find that the coefficient of RELSIZE is positive and significant at $1 \%$ level in both models. If the relative size of the deal increases by $1 \%$, the expected equity payment would increase by $6.5 \%$ while holding all other variables in the model constant. The result, along with the evidence found in the sample of European mergers and acquisitions (Faccio \& Masulis, 2005), underpins Hansen's (1987) argument that purchasing firms should use stock financing to reduce their information asymmetry with regard to the target's market value. The coefficient of TECHSELL is positive and significant at 5\% level, consistent with the argument of Hansen (1987) that purchasing companies prefer to use a greater proportion of stock in a deal if the seller is a high-tech company in order to shorten the asymmetric information problem and share risks between two parties. If the target is a high-tech firm, the expected equity payment would be $60 \%$ higher than in a deal in which the target is not a high-tech firm while holding all other variables in the model constant. Only in model 1 is the coefficient of CROSS negative and significant at 5\% level, offering marginal evidence that the Malaysian acquiring firms are less likely to use stock as the method of payment in cross-border deals.

\subsubsection{Results for the domestic sub-sample of Malaysian acquirers}

Table 7 shows the results for the sub-sample of domestic deals that we obtain from the Tobit model ${ }^{4}$. Regarding the cash constraint variables, we find that the coefficients of DEBT and SIZE are significant at 10\% and 1\% levels respectively. Moreover, the coefficient of RELSIZE is also significant at $1 \%$ level. The sign of the coefficients are consistent with the findings suggested in Table 6, which strengthens our expectation regarding the impact of financial leverage, size of acquirers, and relative size of the deal on the proportion of stock in the payment. On top of that, the marginal effects of the significant variables are similar to those in Table 6.

\section{Table 7}

Regression results for domestic sub-sample

\begin{tabular}{lcc}
\hline \multirow{2}{*}{ Variable } & \multicolumn{2}{c}{ Model 1 } \\
\cline { 2 - 3 } & Coefficient & p-value \\
\hline C & 41.8203 & 0.1170 \\
DEBT & 44.1551 & $0.0840^{*}$ \\
SIZE & -30.1811 & $0.0014^{* * *}$
\end{tabular}




\begin{tabular}{|c|c|c|}
\hline \multirow{2}{*}{ Variable } & \multicolumn{2}{|c|}{ Model 1} \\
\hline & Coefficient & $\mathrm{p}$-value \\
\hline TECHBID & -50.2680 & 0.2667 \\
\hline CRISIS & -16.3654 & 0.2605 \\
\hline SUB & -3.7901 & 0.7828 \\
\hline RELSIZE & 6.3496 & $0.0042 * * *$ \\
\hline TECHSELL & 48.8898 & 0.1073 \\
\hline RELATED & -5.1078 & 0.7384 \\
\hline Adj R-squared & 0.0438 & \\
\hline Total obs. & 270 & \\
\hline
\end{tabular}

Note: $* * *, * *$, and $*$ denote significance levels at $0.01,0.05$ and 0.10 respectively.

5.3.3. Results for the cross-border sub-sample of Malaysian acquirers

Table 8 presents the results obtained from applying the Tobit model to the sub-sample of cross-border deals ${ }^{5}$. There are two models reflecting the target country governance, and only one of them is included in any model. Consistent with the results in the full sample, the coefficients of SIZE and TECHSELL are highly significant. The coefficient of SIZE is negative, whereas that of TECHSELL is positive. If the log of premerger book value of acquirer's assets increases by one point, the expected equity payment would decrease by $12 \%$ while holding all other variables in the model constant. Furthermore, if the target is a high-tech firm, the expected equity payment would be $45 \%$ higher than in a deal in which the target is not a high-tech firm while holding all other variables in the model constant. These results indicate that Malaysian acquirers use more equity when purchasing foreign targets when they are smaller in size and are high technology firms.

\section{Table 8}

Regression results for cross-border sub-sample

\begin{tabular}{|c|c|c|c|c|}
\hline \multirow{2}{*}{ Variable } & \multicolumn{2}{|c|}{ Model 1} & \multicolumn{2}{|c|}{ Model 2} \\
\hline & Coefficient & p-value & Coefficient & $\mathrm{p}$-value \\
\hline C & -16.2788 & 0.8561 & 21.2413 & $0.0717^{*}$ \\
\hline
\end{tabular}




\begin{tabular}{lcccc}
\hline \multirow{2}{*}{ Variable } & \multicolumn{2}{c}{ Model 1 } & \multicolumn{2}{c}{ Model 2 } \\
\cline { 2 - 5 } & Coefficient & p-value & Coefficient & p-value \\
\hline DEBT & 13.5195 & 0.4296 & 12.4347 & 0.4728 \\
SIZE & -12.4886 & $0.0151^{* *}$ & -11.7675 & $0.0061^{* * *}$ \\
TECHBID & -3.5271 & 0.8091 & -2.0576 & 0.8834 \\
CRISIS & 24.5333 & $0.0037 * * *$ & 25.0828 & $0.0019 * * *$ \\
SUB & -20.3264 & 0.1792 & -19.8440 & 0.1747 \\
RELSIZE & 1.5926 & 0.6546 & 1.9921 & 0.5735 \\
TECHSELL & 45.8898 & $0.0414 * *$ & 45.0588 & $0.0441 * *$ \\
RELATED & -1.5685 & 0.8572 & -2.8063 & 0.7328 \\
FREEDOM & 22.0718 & 0.6556 & & 0.6351 \\
COMMON & & & 3.2642 & \\
Adj R-squared & 0.0571 & & 0.1095 & \\
Total obs. & 40 & & 42 & \\
\hline
\end{tabular}

Note: $* * *, * *$, and $*$ denote significance levels at $0.01,0.05$ and 0.10 respectively.

Interestingly, the coefficient of CRISIS is also statistically significant. It is positively significant at $1 \%$ level in both models, suggesting that during the financial crisis periods Malaysian acquirers use more equity to finance their foreign purchasing. There was a shortage of credit during the crisis periods, when the equity proportion increases by $25 \%$ while holding all other variables in the model constant. Thus, the acquirers have to use more equity to finance their investments. Another fascinating point is that Malaysian acquirers are able to convince the targets to accept their equity as a means of payment.

\section{Conclusion}

While a large number of studies related to the method of payment in mergers and acquisitions have been conducted in developed countries, namely the US, the UK, Canada, etc., there is a limited number of research done in developing countries. In this paper, by employing Tobit regression to a large sample of mergers and acquisitions announced and competed during the period of 1995-2012, we examine the role of potential factors influencing the choice of the payment method in takeover transactions 
of Malaysian acquirers. Unlike many previous studies, we find that corporate governance at the national level does not have any impact on the method of payment of Malaysian acquirers. We also document that the financial leverage, the size of acquiring firms, the relative size of the transactions to acquiring firms, and the high technology status of the targets are key determinants to explain the method of payment in transactions of Malaysian acquirers. Moreover, Malaysian acquirers are able to use equity to finance their foreign $\mathrm{M} \& \mathrm{~A}$ transactions during the credit constraint periods

\section{Notes}

${ }^{1}$ There are more characteristics from the bidders that we wish to include in our analysis. However, due to data limitations from Thomson Financial Securities Data's SDC and Compustat global, we cannot collect those for other variables to use in this study.

${ }^{2}$ Summary of the variables that are used to explain the choice of payment method in M\&A transactions of Malaysian acquirers

${ }^{3}$ Tobit regressions explain the portion of stock financing in M\&A transactions of Malaysian acquirers. The estimation is based on a two-boundary Tobit model to reflect lower and upper bound constraints on the percentage of stock used in the transaction. The p-value is based on QML (Huber/White) heteroskedasticity consistent standard errors. DEBT is the total liabilities of acquirer divided by total asset of acquirer. SIZE is the log of premerger book value of acquirer's assets. TECHBID equals 1 if the acquirer is a high-tech firm, and 0 otherwise. CRISIS equals 1 if the transactions happen during 2001-2002 and 2007 crisis, and 0 otherwise. SUB equals 0 if the seller is a public firm, and 1 otherwise. RELSIZE is the relative size of the transaction to the premerger book value of acquirer's assets. TECHSELL equals 1 if the seller is a high-tech firm, and 0 otherwise. RELATED equals 1 if the acquirer and seller have the same two-digit SIC code, and 0 otherwise. CROSS equals 1 if the deal is a cross-border deal, and 0 otherwise. FREEDOM is the natural logarithm of the economic freedom rating of the seller country. COMMON equals 1 if the target country has common law system, and 0 otherwise.

4 Tobit regressions explain the portion of stock financing in domestic transactions of Malaysian acquirers. The other details are the same as the above note.

${ }^{5}$ Tobit regressions explain the portion of stock financing in cross-border transactions of Malaysian acquirers. The other details are the same as the above note.

\section{References}

Amihud, Y., Lev, B., \& Travlos, N. (1990). Corporate control and the choice of investment financing: The case of corporate acquisitions. Journal of Finance, 45, 603-616. 
Arslan, Ö., Florackis, C., \& Ozkan, A. (2006). The role of cash holdings in reducing investment-cash flow sensitivity: Evidence from a financial crisis period in an emerging market. Emerging Markets Review, 7, 320-338.

Bessler, W., Drobetz, W., \& Zimmermann, J. (2011). Financing corporate mergers and acquisitions. In H. K. Baker \& G. S. Martin, Capital structure and corporate financing decisions: Theory, evidence, and practice. NJ: John Wiley \& Sons. doi: 10.1002/9781118266250.ch24

Boateng, A., \& Bi, X.-G. (2014). Acquirer characteristics and method of payment: Evidence from Chinese mergers and acquisitions. Managerial and Decision Economics, 35(8), 540-554.

Boone, A. L., Lie, E., \& Liu, Y. (2014). Time trends and determinants of the method of payment in M\&As. Journal of Corporate Finance, 27, 296-304.

Brown, T., \& Ryngaert, D. (1991). The mode of acquisition in takeovers: Taxes and asymmetric information. Journal of Finance, 46, 653-669.

Bruner, F. (2004). Applied mergers and acquisitions. NJ: John Wiley \& Sons.

Cao, K., \& Madura, J. (2011). Determinants of the method of payment in asset sell-off transactions. Financial Review, 46(4), 643-670.

Chemmanur, T., Paeglis, I., \& Simonyan, K. (2009). The medium of exchange in acquisitions: Does the private information of both acquirer and target matter? Journal of Corporate Finance, 15, 523542.

Faccio, M., \& Masulis, R. (2005). The choice of payment method in European mergers and acquisitions. Journal of Finance, 60, 1345-1388.

Ghosh, A., \& Ruland, W. (1998). Managerial ownership, the method of payment for acquisitions, and executive job retention. Journal of Finance, 53, 785-798.

Hansen, G. (1987). A theory for the choice of exchange medium in mergers and acquisitions. Journal of Business, 60, 75-95.

Harris, M., \& Raviv, A. (1988). Corporate control contests and capital structure. Journal of Financial Economics, 20, 55-86.

Healy, P., Palepu, K., \& Ruback, R. (1992). Does corporate performance improve after takeovers? Journal of Financial Economics, 31, 135-175.

Henisz, W. (2000). The institutional environment for multinational investment. Journal of Law, Economics, and Organization, 16, 334-364.

Heron, R., \& Lie, E. (2002). Operating performance and the method of payment in takeovers. The Journal of Financial and Quantitative Analysis, 37, 137-152.

Ivashina, V., \& Scharfstein, D. (2010). Bank lending during the financial crisis of 2008. Journal of Financial Economics, 97, 319-338.

Johnson, S., Boone, P., Breach, A., \& Friedman, E. (2000). Corporate governance in the Asian financial crisis. Journal of Financial Economics, 58, 141-186. 
Jung, K., Kim, Y., \& Stulz, R. (1996). Timing, investment opportunities, managerial discretion, and the security issue decision. Journal of Financial Economics, 42, 159-185.

Larsen, P. T. (2007). Takeovers reach a record high. The Financial Times. Retrieved from http://www.ft.com/intl/cms/s/0/1705c602-ac19-11db-a0ed-0000779e2340.html\#axzz3uYtBCqx2

Martin, K. (1996). The method of payment in corporate acquisitions, investment opportunities, and management ownership. Journal of Finance, 51, 1227-1246.

Martynova, M., \& Renneboog, L. (2009). What determines the financing decision in corporate takeovers: Cost of capital, agency problems, or the means of payment? Journal of Corporate Finance, 15, 290-315.

Myers, S., \& Majluf, N. (1984). Corporate financing and investment decisions when firms have information that investors do not have. Journal of Financial Economics, 13, 187-221.

Rachel, C., Gomes, A., McGinn, K., \& Noth, M. (2004). Mergers and acquisitions: An experimental analysis of synergies, externalities, and dynamics. Review of Finance, 8, 481-514.

Rappaport, A., \& Sirower, L. (1999). Stock or cash? The trade-offs for buyers and sellers in mergers and acquisitions. Retrieved from https://hbr.org/1999/11/stock-or-cash-the-trade-offs-for-buyersand-sellers-in-mergers-and-acquisition

Rossi, S., \& Volpin, F. (2004). Cross-Country determinants of mergers and acquisitions. Journal of Financial Economics, 74, 277-304.

Servaes, H. (1991). Tobin's Q and the gains from takeovers. Journal of Finance, 46, 409-419.

Song, S. I., Ali, R., \& Pillay, S. (2008). Corporate takeovers in Malaysia: The determinants of postacquisition values of acquiring firms. Capital Market Review, 16(1), 45-63.

Stulz, R. (1988). Managerial control of voting rights: Financial policies and the market for corporate control. Journal of Financial Economics, 20, 25-54.

Sudarsanam, S., \& Mahate, A. (2003). Glamour acquirers, method of payment and post-acquisition performance: The UK evidence. Journal of Business Finance \& Accounting, 30, 299-342.

Travlos, G. (1987). Corporate takeover bids, method of payment, and bidding firms' stock returns. Journal of Finance, 42, 943-963.

Wansley, J., Lane, W., \& Yang, H. (1987). Gains to bidder firms in cash and securities transactions. Financial Review, 22, 403-414. 